\title{
Behaviour of Laterally Anchored Retaining System in Loose Sand Soil
}

\author{
Mostafa El Sawwaf ${ }^{1}$, Ashraf K. Nazir' ${ }^{1}$, W. R. Azzam ${ }^{1}$, Aml M. Elbahkery ${ }^{2}$ \\ ${ }^{1}$ Prof. of geotechnical Engineering, Faculty of Engineering/ Tanta University, Tanta, Egypt \\ ${ }^{2}$ M. SC. Student, Faculty of Engineering, Tanta University/ Tanta, Egypt \\ Email: Mostafa.elsawwaf@f-eng.tanta.edu.eg, Ashraf.Nazir@f-eng.tanta.edu.eg, \\ Azzamwaseim@f-eng.tanta.edu.eg, eng-aml@hotmail.com
}

\begin{abstract}
One of the earliest earth retention technologies used in civil engineering projects is sheet pile walls. Therefore, in this work, a numerical analysis using Plaxis 2D was performed to investigate the behaviour of laterally anchored retaining system in sandy soil, focusing on the anchor force, lateral displacement, and maximum bending moment. The effects of anchor location and number on wall and soil deformations were investigated for various wall heights. When anchored-sheet-piles were used instead of cantilever sheet piles, the results showed a significant reduction in both wall deformation and bending moment specially at high dredging levels. In addition, while having numerous anchor levels is the most approach to minimize wall and soil deformations. Also, the findings revealed that adopting the one-anchored sheet pile wall can greatly decrease the maximum wall displacement by about and 59.16\%; which occurs at $0.4 \mathrm{H}$; as well as reduce the maximum bending moment by about $85.63 \%$; which occurs at $0.5 \mathrm{H}$, comparing with the cantilever sheet pile wall at dredging depth $(\mathrm{H})=5 \mathrm{~m}$. At a deeper dredging depth $(\mathrm{H}=9 \mathrm{~m})$, the maximum lateral displacement and maximum of wall were reduced by $88 \%$, and $86 \%$, respectively. Also, at $\mathrm{H}=9 \mathrm{~m}$, using the second level of anchors can also reduce the maximum bending moment on the wall by more than $83.55 \%$.
\end{abstract}

Index terms: Retaining sheet pile; Penetration depth; Lateral deformation; Maximum bending moment

\section{INTRODUCTION}

Excavation support systems, cut-off walls under dams, cofferdams, waterfront constructions, slope stabilization, and floodwalls are widely used as applications for sheet pile walls. Steel sheet piles are the most prevalent in retaining walls, despite the fact that other materials (such as timber, reinforced concrete, and polymers) are also utilized.

The selection of wall type, either cantilever or anchored, is based on characteristics of foundation soils, the function of wall, and the proximity of wall to existing structures. The conventional methods for designing anchored sheet pile walls are dependent on active and passive earth pressures with the failure condition determined by the Mohr-Coulomb failure criterion. These design methodologies do not take wall displacements into account. An investigation of anchored sheet pile walls via the finite-element method (FEM) by Bjerrum, Frimann [1] also found stress concentration at the anchor level. The stresses calculated from the finite-element analysis (FEA) were higher at the anchor level and above the anchor level, as well as toward the tip of the wall, than the lateral earth stresses assumed in the free earth support method.
The finite element analyses (FEAs) also, found lower active earth pressures between the anchor level and the dredge line. Using finite element analysis, Amer [2] studied wall behavior by varying the soil conditions for both the cantilever and anchored sheet pile walls. It was concluded that increasing wall penetration depth reduces wall deformations for both types of walls, as well as, the bending moments significantly reduced.

Unloading generated by the excavation area, shear deformations of the earth body, elastic deformation of the wall, and soil movement beneath the wall are the cause of the total deformation of the wall [3]. For the cantilever sheet pile wall; the bottom of the wall is assumed not to move, while the top of the wall at the ground is considered to move enough to generate the active and passive earth pressures [4]. On contrary, the displacements at the anchor level are limited when the anchors are utilized. Although the wall can bend between these positions, the overall wall displacements are minimal as compared to the cantilever wall of the same height [4].

There are no firm rules for what constitutes acceptable deflection in sheet pile walls, however values ranging from 1 to 5 inches are commonly accepted. In general, there are different techniques utilized to decrease sheet pile wall deformations. Bilgin and Erten [5] concluded that using multiple anchor levels is the most efficient technique to reduce anchored wall deformations. They found that $50 \%$ reduction in anchored wall deformations is noticed when utilizing larger pile profile, as well as, more than $65 \%$ decrease is observed when using second level of anchors. In addition, placing the anchor at 0.25 of the wall height from the top of wall can result in the least amount of deformations compared with installing the anchor above or below this level [5]. When the anchor stiffness is increased, the maximum wall deformations are lowered by about $50 \%$ in the walls have lower heights. According to Rowe [6], a horizontal displacement at the top of the wall of around 5\% of wall height is the acceptable limit.

Moreover, ultimate passive pressure occurs in loose sand for wall movements between $25 \%$ and $40 \%$ of the wall height, however, for dense sand, movements at ultimate passive resistance are around 5\% of the wall height. Rieke, Crowser [7] showed a failure of a 300-ft-long anchored sheet pile wall during the placement of backfill behind the wall. The cause of the failure is attributed to the loss of stability of underlying soft soils due to large soil and wall deformations. [8] have studied the effect of some parameters such as number of anchors, and friction angle of soil on anchored sheet pile. The results concluded that variation of the friction 
angle has a significant impact on the wall. Moreover, increasing the number of anchors reduces the maximum bending moment, wall displacement, and on contrary, increases the maximum shear force.

A numerical parametric study using the finite element program of PLAXIS was performed on single and double anchored sheet piles systems for sandy [9]. This numerical study aimed at study the effect of varying of some parameters such as the embedded depth, and positions of anchor rods either the upper rod or the lower one. The findings revealed that the forces developed in the lower anchor rods are always higher than those developed in the upper anchor rods.

Finally, in the double anchored sheet pile wall, the lower values of anchor forces and that of maximum bending moments were acquired at the higher soil density. Sowers and Sowers [10] described numerous cases of anchored bulkhead failures. The results concluded that excessive earth pressures, and lack of consideration of effects of construction operations were among the variables leading to anchored sheet pile wall failures. The FEM has been used by researchers to investigate and understand the behavior of cantilever, and anchored sheet pile walls under dynamic and static loading cases [1, 11-20].

\section{GOALS AND OBJECTIVES}

The finite element method has mostly been used for the study of various anchored or braced retaining structures in the past for the excavation cases as mentioned in the introduction. On the other hand, there are a history of failures of anchored sheet pile walls. In addition, various aspects of the anchored sheet pile walls performance are not yet completely understood. This article presents the analysis results and provides recommendations to be utilized in the design of anchored sheet pile walls in order to acquire the optimum straining actions acting on the wall.

The objective of this study was to investigate the deformations of anchored sheet pile walls, and then to study the influence of various parameters in reducing the lateral wall movements and maximum bending moment. Using finite element software package (PLAXIS 2D), parametric study was conducted for varying dredging depth $(\mathrm{H})$, wall type, and number of anchor levels.

\section{NUMERICAL MODELING AND ANALYSES}

\section{A. Numerical Model}

The geotechnical behavior of retaining structures was studied using numerical modeling of cantilever and anchored sheet pile walls at various dredge height $(\mathrm{H})$ values. The plane strain model was used with 15 node elements. A fine mesh was generated by the program. In this investigation, For the case of lateral loads acting on piles or earth pressure on sheet piles under static load, the Mohr- Coulomb model is considered as a suitable model that can be used to simulate the nonlinear behavior of the soil in general due to its simplicity. Furthermore, many researchers have utilized the Mohr-Coulomb model to simulate the drained attitude of granular soils [8, 18, 21-24]. Mohr-Coulomb soil model was utilized to model elasto-plastic behavior of sand soil, which involves five input parameters including Young's modulus
$\left(E_{\mathrm{S}}\right)$; Poisson's ratio (v) for soil elasticity; angle of friction $(\Phi)$ for sand and the angle of dilatancy $(\Psi)$. Since we considered sand soil in this study in the drained case, soil cohesion was set to $\left(1 * 10^{-3} \mathrm{kPa}\right)$ to minimize errors in the numerical analysis as recommended by the Plaxis's manual.

\section{B. Geometry and Material Properties}

A schematic of a typical wall and soil type analyzed is presented in Fig. 1, Fig. 2, and Fig. 3. The parametric study used one soil condition, loose sand, six dredging heights of sheet pile wall, five distances for one anchor sheet pile, and four distances for two anchor sheet pile. The dredging heights $(\mathrm{H})$ investigated in this article were 5, 6, 7, 8 and, 9m Five distances for the one anchor considered were $0.2 \mathrm{H}$, $0.25 \mathrm{H}, 0.3 \mathrm{H}, 0.4 \mathrm{H}$, and $0.5 \mathrm{H}$. Four distances for the second anchor considered were $0.2 \mathrm{H}, 0.3 \mathrm{H}, 0.4 \mathrm{H}$. In each case uniform soil condition was assumed.

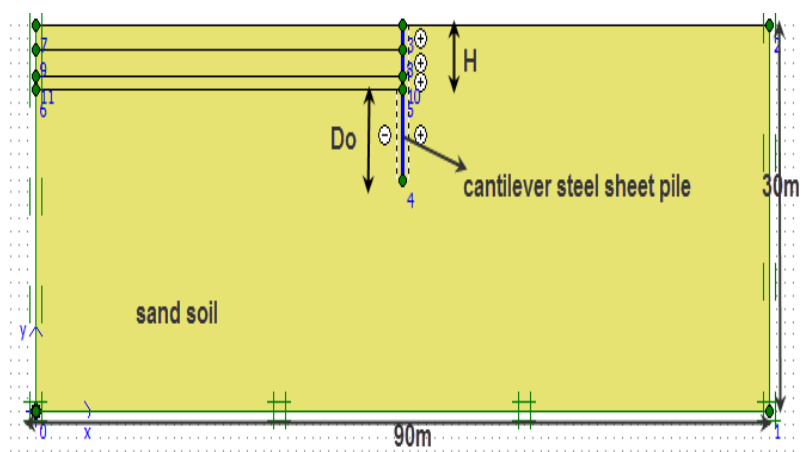

Fig. 1. The geometry of 2D Plaxis model for cantilever sheet pile

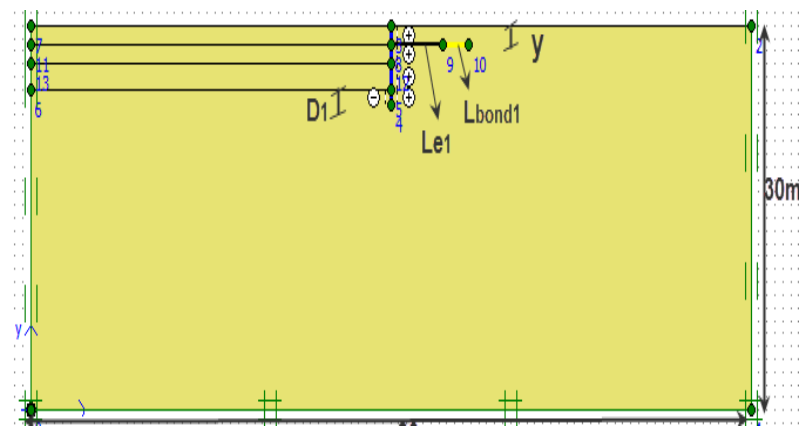

Fig. 2. The geometry of 2D Plaxis model for one anchored sheet pile

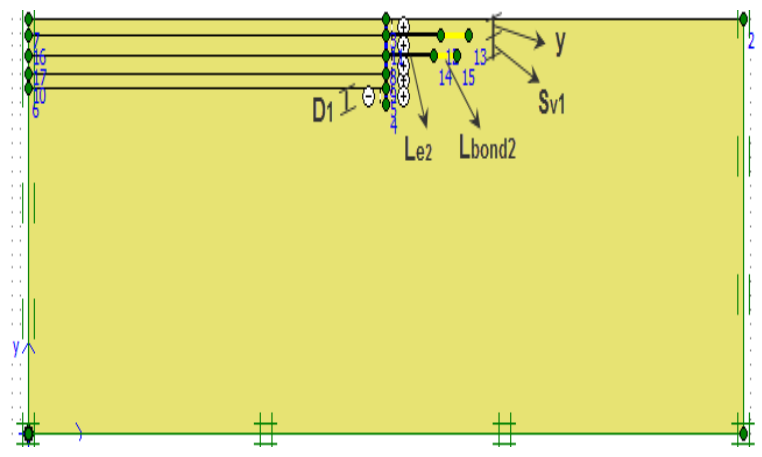

Fig. 3. The geometry of 2D Plaxis model for two anchors sheet pile

Table 1 lists the parameters that were chosen for the sandy soil. The properties chosen for the steel sheet pile are given in Table 2, however, Table 3 shows the properties selected for anchor system. These properties were chosen 
according to Kumar and Dey [24]. The characteristics of the sheet pile wall including the dredging height $(\mathrm{H})$, the penetration depth of cantilever sheet pile $\left(D_{0}\right)$, the penetration depth of anchored sheet pile $\left(D_{1}\right)$, the distance between ground surface and the first anchor $(\mathrm{y})$, the distance between the first and the second anchor $\left(\mathrm{Sv}_{1}\right)$, the effective length $\left(\mathrm{L}_{\mathrm{e}}\right)$, and the grout length $\left(\mathrm{L}_{\mathrm{bond}}\right)$.

Table 1. Properties of sandy soil used for all tests

\begin{tabular}{|c|c|c|}
\hline Parameter & Loose sand & Unit \\
\hline Type of material & Drained & ----- \\
\hline Soil saturated unit weight (gsat) & 16 & $\mathrm{kN} / \mathrm{m} 3$ \\
\hline Soil unsaturated unit weight (gunsat) & 16 & $\mathrm{kN} / \mathrm{m} 3$ \\
\hline Permeability (Kx, Ky) & 1 & $\mathrm{~m} / \mathrm{day}$ \\
\hline Young's modulus (ES) & 24000 & $\mathrm{kN} / \mathrm{m} 2$ \\
\hline Poisson's ratio (u) & 0.33 & ----- \\
\hline Cohesion (c) & 0.001 & $\mathrm{kN} / \mathrm{m}^{2}$ \\
\hline Friction angle ( $\varphi)$ & 30 & ${ }^{\circ}$ \\
\hline Dilatancy angle $(\Psi)$ & 0 & $\circ$ \\
\hline Interface reduction factor (R) & 0.8 & ----- \\
\hline
\end{tabular}

Table 2. Properties of the Sheet Pile Wall (Plate) - Using AZ-48

\begin{tabular}{|c|c|c|c|}
\hline Parameter & Name & Value & Unit \\
\hline $\begin{array}{c}\text { Type of } \\
\text { behavior }\end{array}$ & Material type & Elastic & ---- \\
\hline Normal stiffness & $E A$ & $6.45 \mathrm{E}+06$ & $\mathrm{kN} / \mathrm{m}$ \\
\hline $\begin{array}{c}\text { Bending } \\
\text { stiffness }\end{array}$ & $E I$ & $2.43 \mathrm{E}+05$ & $\mathrm{kN} / \mathrm{m}^{2} / \mathrm{m}$ \\
\hline $\begin{array}{c}\text { Equivalent } \\
\text { thickness }\end{array}$ & $d$ & 0.672 & $\mathrm{~m}$ \\
\hline Weight & $W$ & 15 & $\mathrm{kN} / \mathrm{m}^{2}$ \\
\hline Poisson's ratio & $v$ & 0.3 & - \\
\hline
\end{tabular}

Table 3. Properties of the anchor and the grout part

\begin{tabular}{|c|c|c|c|}
\hline \multirow{2}{*}{ Identification } & \multirow{2}{*}{ Material type } & EA & $\mathrm{L}_{\text {spacing }}$ \\
\cline { 3 - 4 } & & $(\mathrm{kN} / \mathrm{m})$ & $(\mathrm{m})$ \\
\hline Anchor & Elastic & $5.00 \mathrm{E}+05$ & 2.5 \\
\hline grout part & Elastic & $2.00 \mathrm{E}+05$ & -------- \\
\hline
\end{tabular}

Table 4. Variables and ranges used in parametric study

\begin{tabular}{|c|c|c|}
\hline Case & Variable & Range Considered of Anchor depth \\
\hline Wall height & $\mathrm{H}$ & $5 \mathrm{~m}, 6 \mathrm{~m}, 7 \mathrm{~m}, 8 \mathrm{~m}$, and $9 \mathrm{~m}$ \\
\hline No .of anchor & $\mathrm{N}$ & One, and two \\
\hline One anchored & $\mathrm{y}$ & $\begin{array}{c}(0.2 \mathrm{H}, 0.25 \mathrm{H}, 0.3 \mathrm{H}, 0.4 \mathrm{H}, \text { and } 0.5 \\
\mathrm{H})\end{array}$ \\
\hline Two anchored & $\mathrm{S}_{\mathrm{h} 1}$ & $\begin{array}{c}(0.2 \mathrm{H}, 0.3 \mathrm{H}, 0.4 \mathrm{H}, \text { and } 0.5 \mathrm{H}) \text { at } \\
\text { constant } \mathrm{y}=0.2 \mathrm{H}\end{array}$ \\
\hline
\end{tabular}

\section{Numerical Analysis}

The excavation was simulated by removing soil in lifts. The complete excavations were conducted in four steps for at $\mathrm{H}=5 \mathrm{~m}$, and $\mathrm{H}=6 \mathrm{~m}$, five steps at $\mathrm{H}=7 \mathrm{~m}$, and $\mathrm{H}=8 \mathrm{~m}$, and six steps at $\mathrm{H}=9 \mathrm{~m}$. The anchor was installed when excavation reached the anchor level. Because of the cohesionless soils, the analyses were performed considering fully drained conditions. Table 4 lists an outline of the parameters studied in the numerical analyses and their values.

\section{NUMERICAL MODEL VALIDATION}

In this research, analytical studies of the wall system are performed using the finite element program (Plaxis 2D) based on an existing test results [25] as shown in Fig. 4 and illustrated Table 5. The study is made for cohesion less soils with different properties. Furthermore, the total wall height is kept constant while the driven depth, $d$, is varied. In the initial analysis, the driven depth of the wall is assumed to be 1.25 times the free height.

In each subsequent analysis, the driven depth is increased by $0.20 \mathrm{~m}$ while the overall height is remains unchanged. Each time, the horizontal displacement of the top point and the maximum bending moment are measured. The results of analyses for various walls with total heights $(\mathrm{H})$ of 6.75 , 11.25 , and $15.75 \mathrm{~m}$ are presented.

Where:

$\mathrm{H}_{\mathrm{w}}$ : Free height of the wall is considered $(3,5,7) \mathrm{m}$ $\mathrm{d}$ : Driven depth of the wall is considered $1.25 \mathrm{H}_{\mathrm{w}}$ H: Total Height of the wall,

hi: Increase in driven depth, (Decrease in free height)

The soil profile consists of a medium dense sand layer with $\Phi=28$.

The validation results indicated a good agreement with the model in the instance of the relationship among the maximum bending moment on the wall versus increasing in the driven depth for the three wall heights as well as plots of the lateral displacement versus increase in driven depth as presented in Fig. 5, and Fig. 6, respectively.

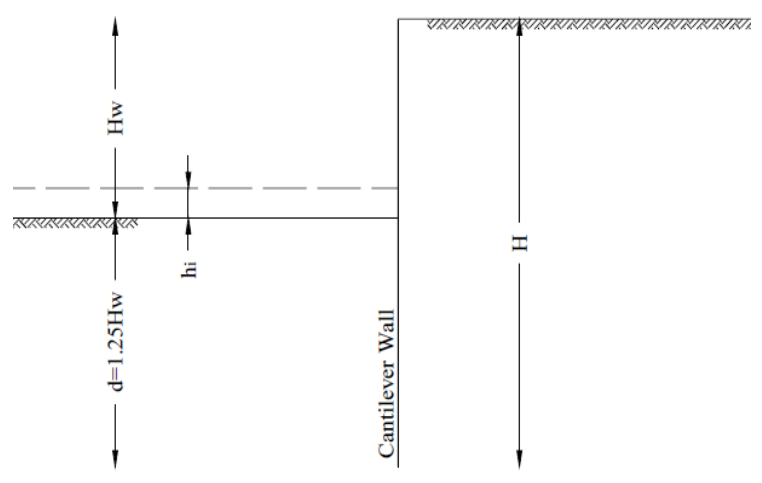

Fig. 4. Typical mesh dimensions for sheet pile wall, [25]

Table 5. Properties of sheet pile Wall, Morsi [25]

\begin{tabular}{|c|c|c|}
\hline No. & Property & Group (1) \\
\hline 1. & Flexural rigidity per meter & 1.26 E7 \\
\hline 2. & Axial stiffness per meter & 3.78 E5 \\
\hline 3. & Unit weight per meter & 15.00 \\
\hline 4. & Poisson's Ratio & 0.25 \\
\hline 5. & Equivalent wall thickness & 0.60 \\
\hline
\end{tabular}

Increasing dredging height $(\mathrm{H})$ on the behaviour of walls is pretty similar at all dredging heights, indicated to the same trends, i.e. increase the dredging height $(\mathrm{H})$ resulting in increasing the horizontal displacements of walls, as well as, in case of higher cantilever walls, large values of bending moments were observed compared to relatively shorter walls, as expected. 


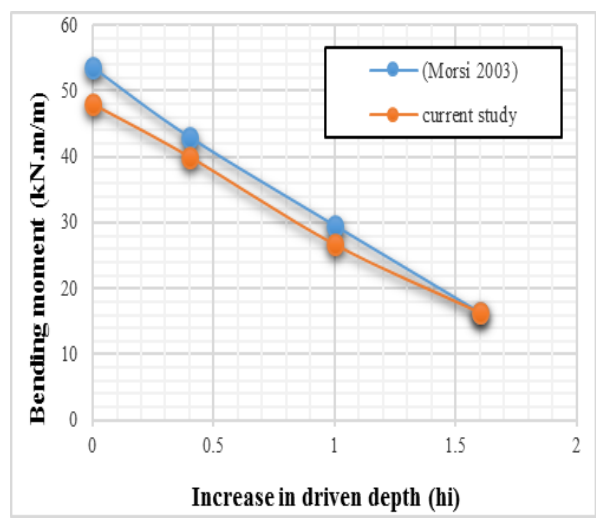

Fig. 5. Maximum moment versus increase of Driven Depth $\left(\mathrm{Hw}=3.0 \mathrm{~m} \& \phi=28^{\circ}\right)$



Fig. 6. Deflection of the Wall versus Increase of Driven Depth $\left(\mathrm{Hw}=3.0 \mathrm{~m} \& \phi=28^{\circ}\right)$

\section{RESULTS AND ANALYSIS}

\section{A. Behavior of The Cantilever Sheet Pile Wall}

Figure 7 depicts the analysis results in terms of walls displacements and bending moment. The influence of increasing dredging height $(\mathrm{H})$ on the behaviour of walls is pretty similar at all dredging heights, indicated to the same trends, i.e. increase the dredging height $(\mathrm{H})$ resulting in increasing the horizontal displacements of walls, as well as, in case of higher cantilever walls, large values of bending moments were observed compared to relatively shorter walls, as expected.

\section{B. Behavior of the anchored sheet pile wall}

First set of analysis was conducted to study the impact of anchor depth on wall deformations. The first anchor measured from the wall's top, and the second anchor measured from the first anchor. The influence of anchor location on deformations of the wall at various dredging heights and different types of sheet pile has been investigated. These deformations were estimated at three points as follows:

1- The horizontal displacement at the beginning of excavation is shown in Figs. 8, 9, 14, 15, and 16 as well as, concluded in Tables 6 , and 12 .

2- At the point of maximum wall horizontal displacement which shown in Figs. 10, 11, 17, and 18 as well as, concluded in Tables 7, 8, 13, 18 and 14.

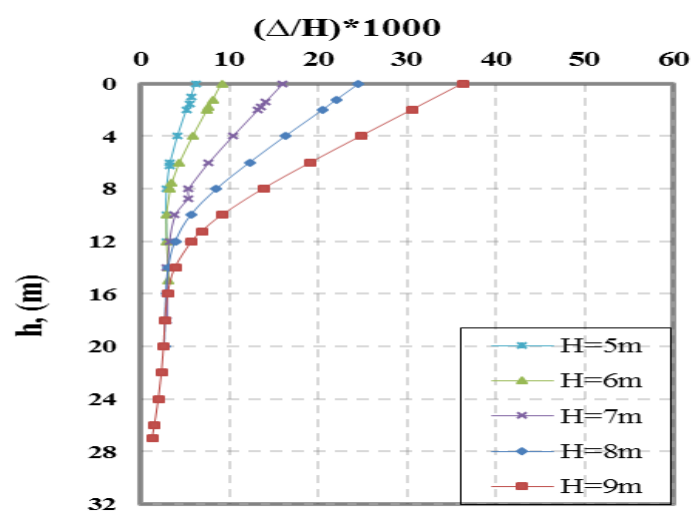

(a) Lateral displacement

Moment ( $\mathbf{k N}$. m/m)

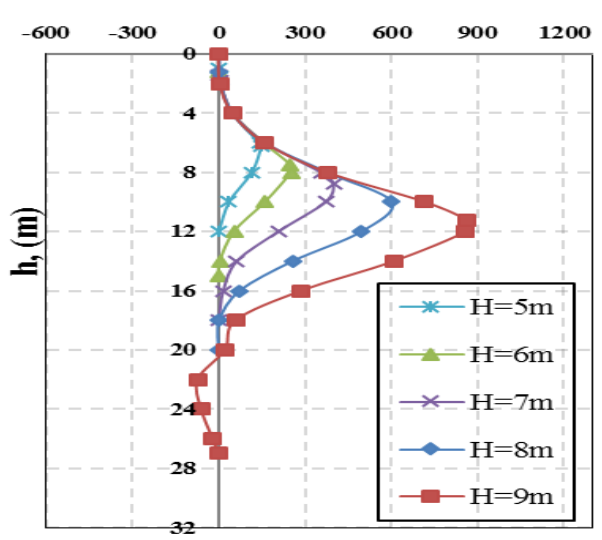

(b) bending moment

Fig. 7. Comparison of bending moment and lateral displacement with depth for cantilever sheet pile wall.

3- At the point of maximum bending moment which illustrated in Figs. 12, 13, 14, 19, 20, and 21, as well as, concluded in Tables 9, 10, 15, and 16 .

\section{- $\quad$ Result of the one anchored sheet pile wall}

From the current investigation, after studying the behavior of the cantilever sheet pile walls as shown in Fig. 2, the anchored sheet pile wall was utilized to reduce the penetration depth, as well as, minimize the horizontal displacement of the wall and the bending moment acting on it. A single anchor was investigated at different distances and measured from the surface of the ground or from the top of the wall.

The lateral displacement and bending moment were investigated at different locations; such as 1- at the wall top and presented in Fig. 8, and Fig. 9 and Table 6, 2- at the point of maximum lateral displacement; which occurred as presented in Table 7; and shown in Fig. 10, and Fig. 11 and Table 8, and 3- at the point of maximum bending moment; which occurred as presented in Table 9; as shown in Fig. 12, Fig. 13, Fig. 14, and Table 10. The reduction percentages were measured in each case compared to the cantilever sheet pile wall case, as well as, the anchor forces are also found at various places as shown Table 10 .

\section{1) At the top of the sheet pile wall}

At the wall top, the results indicate that the highest percentage of reduction in the horizontal displacement was 
at $\mathrm{y} / \mathrm{H}=0.2$. The same observations were found for all dredging depths at $\mathrm{D}=0.25 \mathrm{H}$. The reduction percentages were $68 \%, 76 \%, 83 \%, 86 \%$, and $91 \%$ at $\mathrm{H}=5 \mathrm{~m}, 6 \mathrm{~m}, 7 \mathrm{~m}$, $8 \mathrm{~m}$, and $9 \mathrm{~m}$, respectively, comparing with the cantilever sheet pile.



Fig. 8. Variation of the horizontal displacement $(\Delta)$ at different wall height $(\mathrm{H})$.

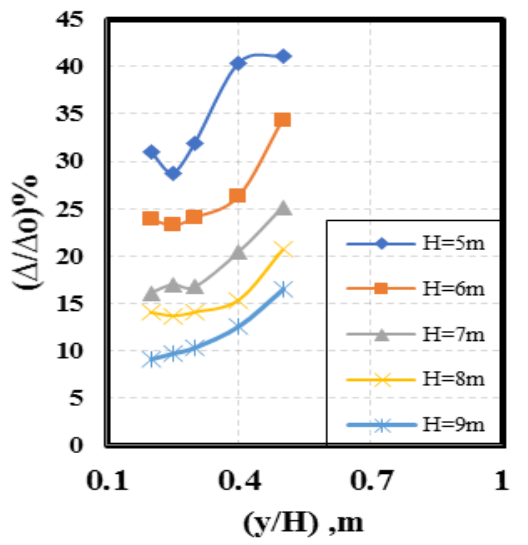

(a)

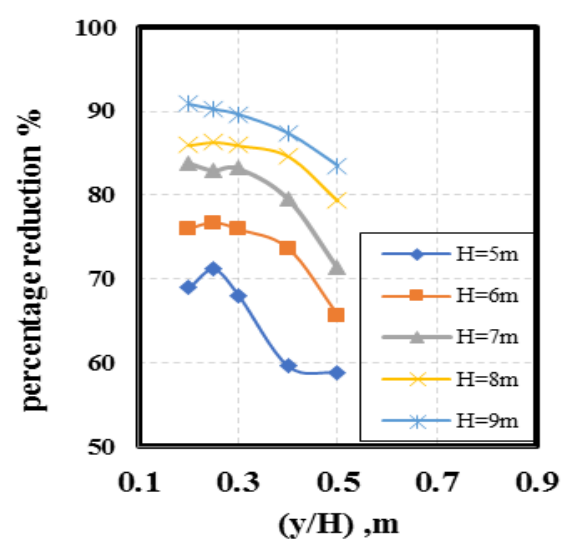

(b)

Fig. 9. Variation of a) the ratio of the lateral displacement to lateral displacement of anchored sheet pile to cantilever wall ( $\Delta / \Delta \mathrm{o})$, and b) reduction percentage of horizontal displacement with $\mathrm{y} / \mathrm{H}$ at different wall height $(\mathrm{H})$.

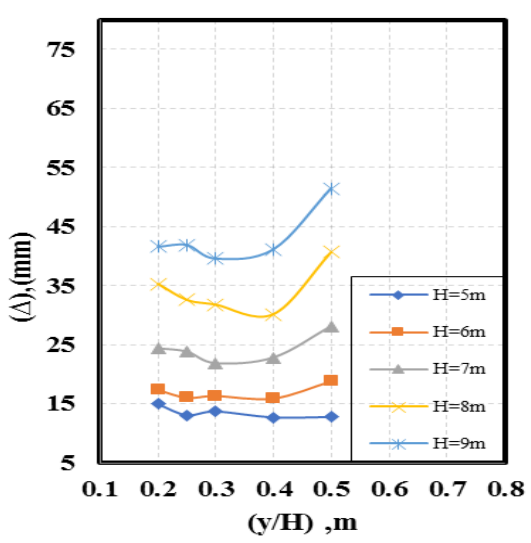

(a)

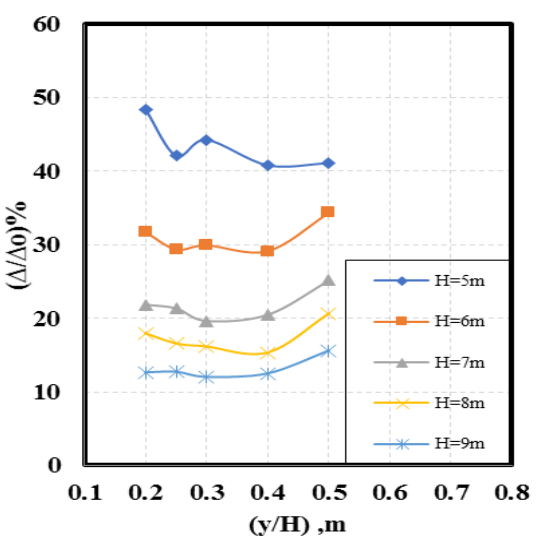

(b)

Fig.10. Variation of a) horizontal displacement $(\Delta)$, b) the ratio of the lateral displacement of anchored sheet pile to lateral displacement of cantilever wall $(\Delta / \Delta \mathrm{o})$, and $\mathrm{b})$ reduction percentage of horizontal displacement with $\mathrm{y} / \mathrm{H}$ at different wall height $(\mathrm{H})$. 
Table 6. The values of lateral displacement, $(\mathrm{mm})$ and the percent of decreasing in lateral displacement at different $\mathrm{y} / \mathrm{H}$ distances.

\begin{tabular}{|c|c|c|c|c|c|c|c|c|c|c|}
\hline & \multicolumn{2}{|c|}{$5 \mathrm{~m}$} & \multicolumn{2}{|c|}{$6 \mathrm{~m}$} & \multicolumn{2}{|c|}{$7 m$} & \multicolumn{2}{|c|}{$8 m$} & \multicolumn{2}{|c|}{$9 \mathrm{~m}$} \\
\hline$\underset{D}{\mathbb{N}}$ & $\triangleleft$ & 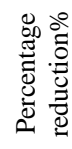 & $\triangleleft$ & 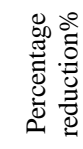 & $\triangleleft$ & 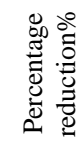 & $\triangleleft$ & 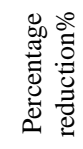 & $\triangleleft$ & 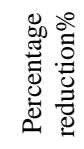 \\
\hline 0.2 & 9.59 & 69 & 13.12 & 76.03 & 18 & 83.88 & 27.5 & 85.99 & 29.75 & 90.9 \\
\hline 0.25 & 8.91 & 71.2 & 12.74 & 76.73 & 19 & 83 & 26.8 & 86.35 & 31.71 & 90.3 \\
\hline 0.3 & 9.88 & 68.1 & 13.19 & 75.91 & 18.7 & 83.25 & 27.54 & 85.97 & 33.76 & 89.7 \\
\hline 0.4 & 12.49 & 59.6 & 14.43 & 73.63 & 22.8 & 79.62 & 30.12 & 84.66 & 41.12 & 87.42 \\
\hline 0.5 & 12.72 & 58.9 & 18.82 & 65.62 & 32.1 & 71.32 & 40.62 & 79.31 & 53.74 & 83.6 \\
\hline
\end{tabular}

Table 7. The locations of the ratio $(\mathrm{h} / \mathrm{H}),(\mathrm{m})$ at different $\mathrm{y} / \mathrm{H}$ distances for various dredging height $(\mathrm{H})$

\begin{tabular}{|c|c|c|c|c|c|}
\cline { 2 - 6 } \multicolumn{1}{c|}{} & \multicolumn{5}{c|}{$(\mathrm{h} / \mathrm{H})$} \\
\hline $\mathrm{y} / \mathrm{H}$ & $5 \mathrm{~m}$ & $6 \mathrm{~m}$ & $7 \mathrm{~m}$ & $8 \mathrm{~m}$ & $9 \mathrm{~m}$ \\
\hline 0.2 & 1.25 & 0.96 & 0.79 & 0.69 & 0.67 \\
\hline 0.25 & 1.25 & 0.88 & 0.79 & 0.69 & 0.67 \\
\hline 0.3 & 1.1 & 0.92 & 0.73 & 0.69 & 0.67 \\
\hline 0.4 & 1 & 0.83 & 0 & 0 & 0 \\
\hline 0.5 & 0 & 0 & 0 & 0 & 0 \\
\hline
\end{tabular}

Table 8. The values of lateral displacement, $(\mathrm{mm})$ and the percent of decreasing in lateral displacement due at different $\mathrm{y} / \mathrm{H}$ distances

\begin{tabular}{|c|c|c|c|c|c|c|c|c|c|c|}
\hline & \multicolumn{2}{|c|}{$5 \mathrm{~m}$} & \multicolumn{2}{|c|}{$6 \mathrm{~m}$} & \multicolumn{2}{|c|}{$7 \mathrm{~m}$} & \multicolumn{2}{|c|}{$8 \mathrm{~m}$} & \multicolumn{2}{|c|}{$9 m$} \\
\hline$\underset{\lambda}{\mathbb{R}}$ & $\triangleleft$ & 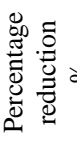 & $\triangleleft$ & 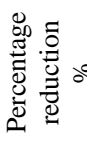 & $\triangleleft$ & 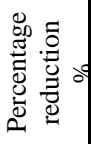 & $\triangleleft$ & 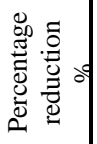 & $\triangleleft$ & 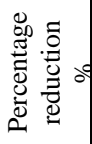 \\
\hline 0.2 & 15 & 51.6 & 17.38 & 68.27 & 24.4 & 78.14 & 35.3 & 82.02 & 41.55 & 87.37 \\
\hline 0.25 & 13.04 & 57.9 & 16.08 & 70.6 & 23.8 & 78.65 & 32.57 & 83.4 & 41.86 & 87.28 \\
\hline 0.3 & 13.7 & 55.7 & 16.38 & 70.1 & 21.8 & 80.4 & 31.75 & 83.83 & 39.56 & 87.98 \\
\hline 0.4 & 12.64 & 59.2 & 15.95 & 70.9 & 22.8 & 79.55 & 30.12 & 84.66 & 41.12 & 87.5 \\
\hline 0.5 & 12.73 & 58.9 & 18.82 & 65.6 & 28.1 & 74.8 & 40.63 & 79.34 & 51.44 & 84.36 \\
\hline
\end{tabular}

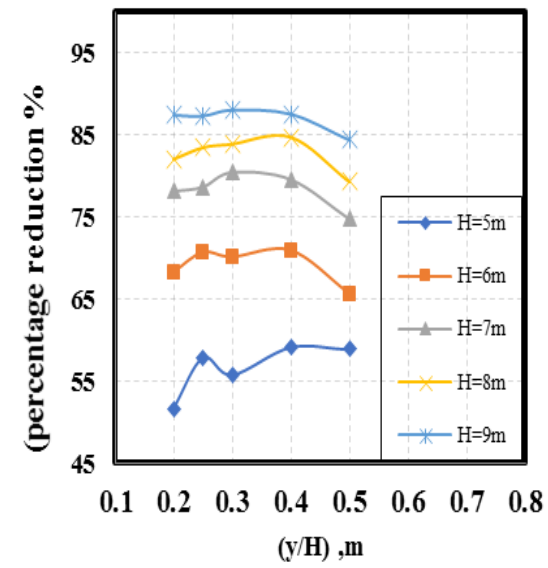

Fig. 11. Variation reduction of horizontal displacement percentage with $\mathrm{y} / \mathrm{H}$ at different wall height $(\mathrm{H})$

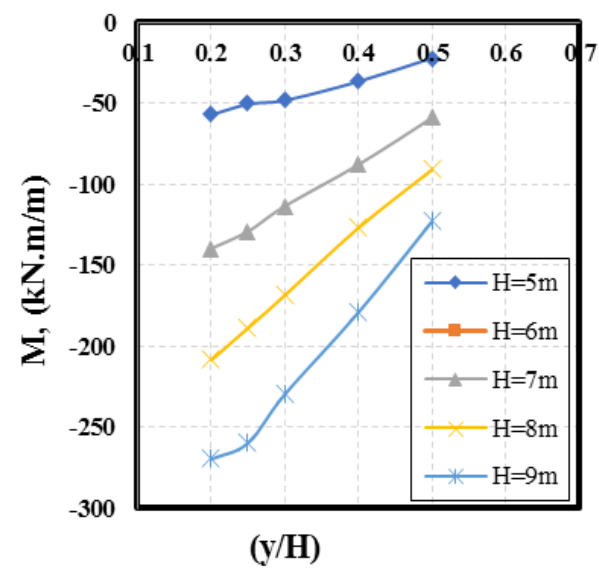

Fig. 12. Variation of bending moment at different wall height $(\mathrm{H})$ 


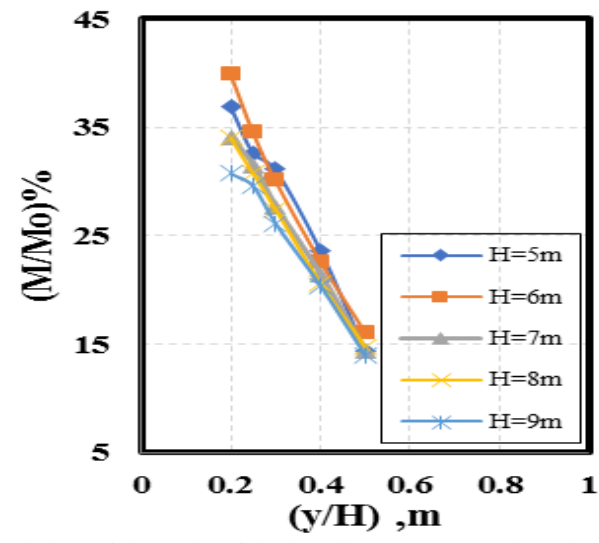

Fig. 13. Variation of the ratio of the bending moment to bending moment of anchored sheet pile to cantilever wall at different wall height $(\mathrm{H})$.

Table 9. The locations of the ratio $(\mathrm{h} / \mathrm{H}),(\mathrm{m})$ at different $\mathrm{y} / \mathrm{H}$ distances for various wall height $(\mathrm{H})$

\begin{tabular}{|c|c|c|c|c|c|}
\cline { 2 - 6 } \multicolumn{1}{c|}{} & \multicolumn{5}{c|}{$(\mathrm{h} / \mathrm{H})$} \\
\hline $\mathrm{y} / \mathrm{H}$ & $5 \mathrm{~m}$ & $6 \mathrm{~m}$ & $7 \mathrm{~m}$ & $8 \mathrm{~m}$ & $9 \mathrm{~m}$ \\
\hline 0.2 & 0.8 & 0.75 & 0.7 & 0.75 & 0.8 \\
\hline 0.25 & 0.8 & 0.75 & 0.79 & 0.75 & 0.8 \\
\hline 0.3 & 0.8 & 0.75 & 0.84 & 0.81 & 0.8 \\
\hline 0.4 & 0.85 & 0.83 & 0.84 & 0.81 & 0.8 \\
\hline 0.5 & 0.9 & 0.92 & 0.9 & 0.88 & 0.89 \\
\hline
\end{tabular}

Table 10. The values of maximum bending moment, $(\mathrm{kN} . \mathrm{m} / \mathrm{m})$ and the percent of decreasing in bending moment at different $\mathrm{y} / \mathrm{H}$ distances.

\begin{tabular}{|c|c|c|c|c|c|c|c|c|c|c|}
\hline & \multicolumn{2}{|c|}{ Sm } & \multicolumn{2}{|c|}{$6 \mathrm{~m}$} & \multicolumn{2}{|c|}{$7 \mathrm{~m}$} & \multicolumn{2}{|c|}{$8 \mathrm{~mm}$} & \multicolumn{2}{|c|}{9} \\
\hline yH & $\mathrm{Man}$ & 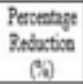 & $\mathrm{Ma}$ & 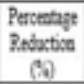 & $\mathrm{M}$ & 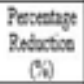 & $\mathrm{Man}$ &  & $\mathrm{Men}$ & 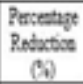 \\
\hline 02 & .56 .7 & 63.1 & -1003 & 60.1 & -139.7 & 659 & 2079 & 66.0 & -269.2 & 693 \\
\hline 0.25 & .50 .2 & 673 & .868 & 65.5 & -129.1 & 68.5 & -188.1 & 693 & 259.2 & 20.4 \\
\hline 0.3 & 479 & 68.8 & .756 .6 & 69.9 & .113 .4 & 723 & -1679 & 72.6 & 220. & 73.8 \\
\hline 0.4 & .364 & 76.3 & .569 & 77.4 & .878 & 78.6 & 126.5 & 793 & -178.7 & 79.6 \\
\hline 0.5 & .221 & 85.6 & 40.4 & 839 & .588 & 856 & 90.5 & 852 & -1225 & 860 \\
\hline
\end{tabular}

Table 11. The values of the force in the anchor at various $\mathrm{y} / \mathrm{H}$ distances at different wall height $(\mathrm{H})$

\begin{tabular}{|c|c|c|c|c|c|}
\hline \multirow{2}{*}{$\mathrm{y} / \mathrm{H}$} & \multicolumn{5}{|c|}{ Force in the one-anchored sheet pile wall } \\
\cline { 2 - 6 } & \multicolumn{5}{|c|}{$\mathrm{kN}$} \\
\cline { 2 - 6 } & $\mathrm{H}=5 \mathrm{~m}$ & $\mathrm{H}=6 \mathrm{~m}$ & $\mathrm{H}=7 \mathrm{~m}$ & $\mathrm{H}=8 \mathrm{~m}$ & $\mathrm{H}=9 \mathrm{~m}$ \\
\hline 0.2 & 51.0 & 63.1 & 81.4 & 114.7 & 132.9 \\
\hline 0.25 & 49.2 & 61.6 & 87.5 & 112.5 & 150.7 \\
\hline 0.3 & 50.7 & 66.0 & 81.57 & 119.1 & 150.2 \\
\hline 0.4 & 59.7 & 67.4 & 91.08 & 122.3 & 161.6 \\
\hline 0.5 & 54.9 & 75.5 & 98.45 & 131.6 & 172.0 \\
\hline
\end{tabular}

From the aforementioned results, it is clear that the lowest value of the anchor force at all dredging depths occur at $\mathrm{y} / \mathrm{H}=0.2$. In addition, with increasing the dredging depth value $(\mathrm{H})$, the Anchor force increases. Thereby, the lowest value of the anchor force was at $\mathrm{H}=5 \mathrm{~m}$ and the largest value was at $\mathrm{H}=9 \mathrm{~m}$, as expected. The findings also

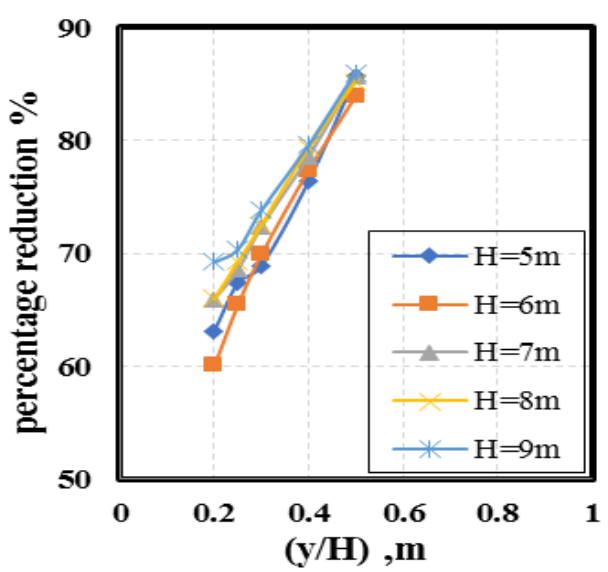

Fig. 14. Variation of the reduction percentage of the bending moment with $\mathrm{y} / \mathrm{H}$ at different wall height $(\mathrm{H})$.

concluded that the best position for the first anchor is at $y / H$ $=0.2-0.25$ for the horizontal displacement, however, for the moment, the best position $\mathrm{s}$ at $\mathrm{y} / \mathrm{H}=0.5$. Therefore, in order to study the two-anchored sheet pile, the first anchor is placed at a constant position $(\mathrm{y} / \mathrm{H}=0.2)$.

- Result of the two anchored sheet pile walls

After investigating the behavior of the one-anchored sheet pile walls, the two-anchored sheet pile wall was examined in order to decrease the penetration depth as well as minimize both of the wall horizontal displacement and bending moment. The first anchor was set at a certain depth $(y=0.2 \mathrm{H})$ and the position of the second anchor was examined at different distances from the first anchor. Both of the lateral displacement and bending moment were investigated at various locations such as at the wall top and shown in Fig. 14, Fig. 15, and Fig.16 and presented in Table 12 , at the point of maximum lateral displacement; which occurred as tabulated in Table 13; and shown in Fig. 17, and Fig.18 and Table 14, and at the point of maximum bending moment; which occurred as presented in Table 15; and shown in Fig. 19,Fig.20 ,and Fig.21 and Table 16.

The percentages of reduction were measured in each case compared to the cantilever sheet pile wall case, as well as, the anchor forces are also calculated at various positions where the anchors were placed, as shown Table 16.

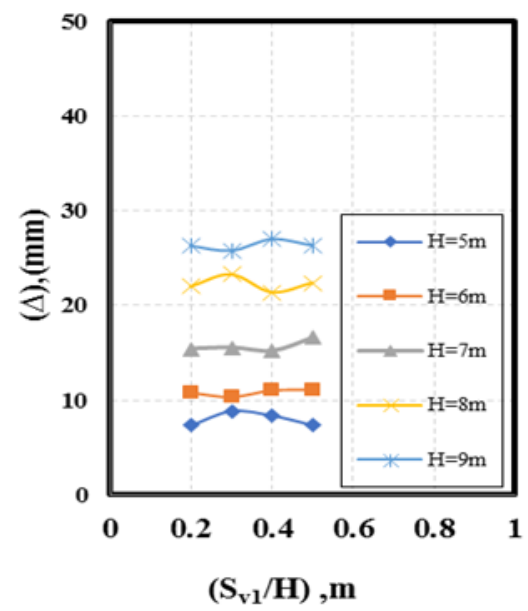

Fig. 14. Variation of lateral displacement at different wall height $(\mathrm{H})$. 


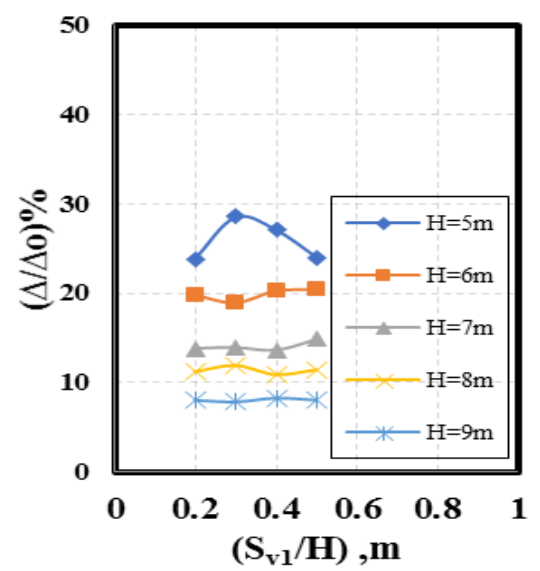

Fig. 15. Variation of the ratio of the lateral displacement of anchored sheet pile to lateral displacement of cantilever wall $(\Delta / \Delta \mathrm{o})$ at different wall height $(\mathrm{H})$.

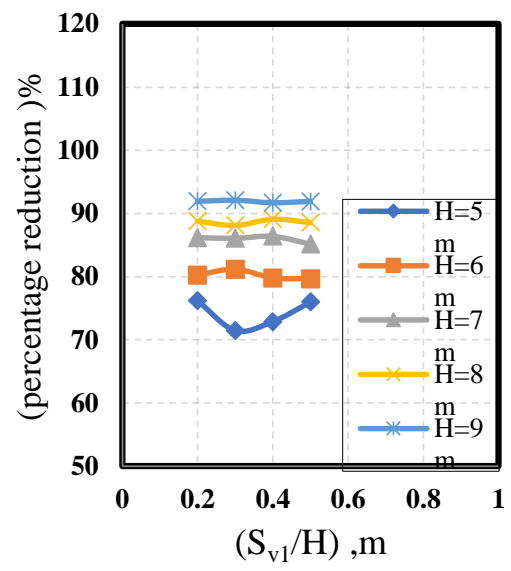

Fig. 16. Variation of the reduction percentage of lateral displacement with $\mathrm{S}_{\mathrm{v} 1} / \mathrm{H}$ at different wall height $(\mathrm{H})$

Table 12. The values of lateral displacement, $(\mathrm{mm})$ and the percent of decreasing in lateral displacement at different $\mathrm{S}_{\mathrm{v} 1} / \mathrm{H}$ distances.

\begin{tabular}{|c|c|c|c|c|c|c|c|c|c|c|}
\hline & \multicolumn{2}{|c|}{$5 \mathrm{~m}$} & \multicolumn{2}{|c|}{$6 \mathrm{~m}$} & \multicolumn{2}{|c|}{$7 \mathrm{~m}$} & \multicolumn{2}{|c|}{$8 \mathrm{~m}$} & \multicolumn{2}{|c|}{$9 \mathrm{~m}$} \\
\hline $\begin{array}{l}\text { 出 } \\
\text { 点 }\end{array}$ & $\triangleleft$ & 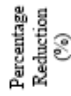 & $\triangleleft$ & 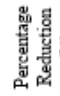 & $\triangleleft$ & 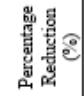 & 4 & 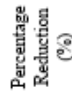 & 4 & 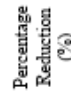 \\
\hline 0.2 & 7.4 & 76.1 & 10.8 & 80.3 & 15.4 & 86.2 & 21.98 & 88.8 & 26.3 & 91.95 \\
\hline 0.3 & 8.84 & 71.5 & 10.3 & 81.2 & 15.6 & 86.1 & 23.3 & 88.14 & 25.8 & 92.11 \\
\hline 0.4 & 8.4 & 72.9 & 11.1 & 79.8 & 15.2 & 86.41 & 21.4 & 89.12 & 26.98 & 91.74 \\
\hline 0.5 & 7.4 & 75.99 & 11.1 & 79.7 & 16.6 & 85.2 & 22.4 & 88.6 & 26.35 & 91.94 \\
\hline
\end{tabular}



Fig. 14. Variation of lateral displacement $(\Delta)$,at different $\mathrm{S}_{\mathrm{v} 1} / \mathrm{H}$ distances.

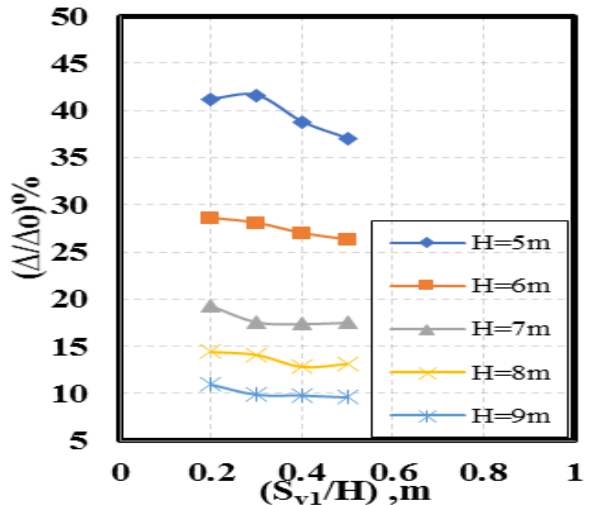

(a)

Fig. 17. Variation of the ratio of the lateral displacement of anchored sheet pile to lateral displacement of cantilever wall $(\Delta / \Delta \mathrm{o})$ at different wall height $(\mathrm{H})$.

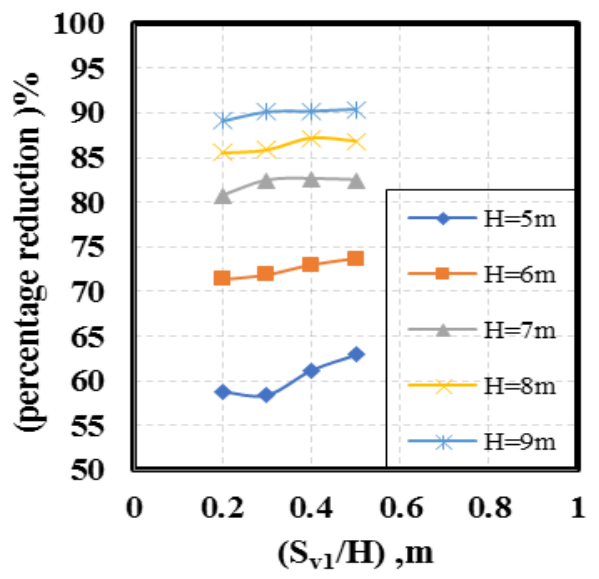

Fig. 18. Variation of the ratio of the reduction percentage of lateral displacement with $\mathrm{S}_{\mathrm{v} 1} / \mathrm{H}$ at different wall height $(\mathrm{H})$.

Table 13. The locations of the ratio $\left(\mathbf{S}_{\mathbf{v} 1} \mathrm{H}\right),(\mathrm{m})$ at different $\mathrm{S}_{\mathrm{v}} / \mathrm{H}$ distances for various dredging height $(\mathrm{H})$.

\begin{tabular}{|c|c|c|c|c|c|}
\cline { 2 - 6 } \multicolumn{1}{c|}{} & \multicolumn{5}{c|}{$(\mathrm{h} / \mathrm{H})$} \\
\hline $\mathrm{S}_{\mathrm{v} 1} / \mathrm{H}$ & $5 \mathrm{~m}$ & $6 \mathrm{~m}$ & $7 \mathrm{~m}$ & $8 \mathrm{~m}$ & $9 \mathrm{~m}$ \\
\hline 0.2 & 1.25 & 1.25 & 0.95 & 0.81 & 0.78 \\
\hline 0.3 & 1.25 & 1.25 & 0.84 & 0.75 & 0.728 \\
\hline 0.4 & 1.25 & 1.25 & 0.81 & 0.75 & 0.73 \\
\hline 0.5 & 1.25 & 1.03 & 0.78 & 0.65 & 0.64 \\
\hline
\end{tabular}

Table 14. The values of lateral displacement, $(\mathrm{mm})$ and the percent of decreasing in lateral displacement due at different $\mathrm{S}_{\mathrm{v} /} / \mathrm{H}$ distances.

\begin{tabular}{|c|c|c|c|c|c|c|c|c|c|c|}
\hline & \multicolumn{2}{|c|}{$5 \mathrm{~m}$} & \multicolumn{2}{|c|}{$6 \mathrm{~m}$} & \multicolumn{2}{|c|}{$7 \mathrm{~m}$} & \multicolumn{2}{|c|}{$8 \mathrm{~m}$} & \multicolumn{2}{|c|}{$9 \mathrm{~m}$} \\
\hline $\begin{array}{l}\text { 焉 } \\
\text { h }\end{array}$ & $\triangleleft$ & 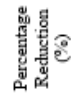 & 4 & 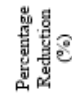 & 4 & 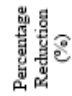 & $\triangleleft$ & 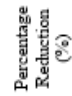 & 4 & 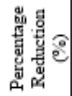 \\
\hline 0.2 & 12.8 & 58.8 & 15.7 & \begin{tabular}{|l|}
71.4 \\
\end{tabular} & 21.6 & 80.7 & 28.4 & 85.54 & 36.01 & 89.05 \\
\hline 0.3 & 12.9 & 58.42 & 15.4 & 71.9 & 19.7 & 82.4 & 27.76 & 85.9 & 32.61 & 90.1 \\
\hline 0.4 & 12.01 & 61.2 & 14.8 & \begin{tabular}{|l|}
72.99 \\
\end{tabular} & 19.5 & 82.6 & 25.274 & 87.13 & 32.34 & 90.2 \\
\hline 0.5 & 11.5 & 62.94 & 14.42 & 73.7 & 19.6 & 82.5 & 25.89 & 86.8 & 31.68 & 90.4 \\
\hline
\end{tabular}

\section{1) At the top of the sheet pile wall}

At the wall top, the results indicate that the highest percentage of reduction in the horizontal displacement was at $\mathbf{S}_{\mathbf{v} 1} / \mathrm{H}=0.2$ at $\mathrm{H}=5 \mathrm{~m}, 6 \mathrm{~m}$, and $9 \mathrm{~m}$, however, occurred at 
$\mathbf{S}_{\mathbf{v} 1} / \mathrm{H}=0.3$ at $\mathrm{H}=7 \mathrm{~m}$, and $8 \mathrm{~m}$ at $\mathrm{D}=0.25 \mathrm{H}$. The reduction percentages were $76.1 \%, 81.2 \%, 86.41 \%, 89.12 \%$, and 91.95 $\%$ at $\mathrm{H}=5 \mathrm{~m}, 6 \mathrm{~m}, 7 \mathrm{~m}, 8 \mathrm{~m}$, and $9 \mathrm{~m}$, respectively, comparing with the cantilever sheet pile.

\section{2) At the point of maximum lateral displacement}

The highest percentage of reduction in the horizontal displacement was at $\mathrm{S}_{\mathrm{v} 1} / \mathrm{H}=0.3$ at $\mathrm{H}=7 \mathrm{~m}, 8 \mathrm{~m}$, and $9 \mathrm{~m}$, however, occurred at $\mathrm{S}_{\mathrm{v} 1} / \mathrm{H}=0.4$ at $\mathrm{H}=5 \mathrm{~m}, 6 \mathrm{~m}$, and $10 \mathrm{~m}$ at $\mathrm{D}=0.25 \mathrm{H}$. The reduction percentages were $62.94 \%, 73.7 \%$, $82.6 \%, 87.13 \%, 90.2 \%$, and $92.25 \%$ at $\mathrm{H}=5 \mathrm{~m}, 6 \mathrm{~m}, 7 \mathrm{~m}, 8 \mathrm{~m}$, $9 \mathrm{~m}$, and $10 \mathrm{~m}$, respectively, comparing with the cantilever sheet pile the point of maximum displacement, the results indicate that.

\section{3) At the point of maximum bending moment}

At the point of maximum moment, the results indicate that the highest percentage of reduction in the bending moment was at $\mathbf{S}_{\mathbf{v} 1} / \mathrm{H}=0.4$ for all dredging heights $(\mathrm{H}=5 \mathrm{~m}$, $6 \mathrm{~m}, 7 \mathrm{~m}, 8 \mathrm{~m}, 9 \mathrm{~m}$, and $10 \mathrm{~m})$. The reduction percentages were $80.8 \%, 78.9 \%, 81.4 \%, 82.92 \%, 83.55 \%$, and $85.54 \%$ at $\mathrm{H}=$ $5 \mathrm{~m}, 6 \mathrm{~m}, 7 \mathrm{~m}, 8 \mathrm{~m}, 9 \mathrm{~m}$, and $10 \mathrm{~m}$, respectively, comparing with the cantilever sheet pile.

From the aforementioned results, it is clear that the lowest value of the anchor force at all dredging depths occur at $\mathbf{S}_{\mathbf{v} 1} / \mathbf{H}=0.2$. In addition, with increasing the dredging depth value $(\mathrm{H})$, the Anchor force increases. Thereby, the lowest value of the anchor force was at $\mathrm{H}=5 \mathrm{~m}$ and the largest value was at $\mathrm{H}=10 \mathrm{~m}$.

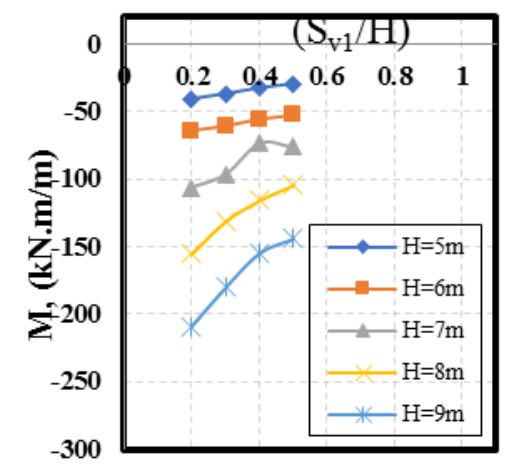

Fig. 19. Variation of bending moment $(\mathrm{M})$ at different wall height $(\mathrm{H})$.

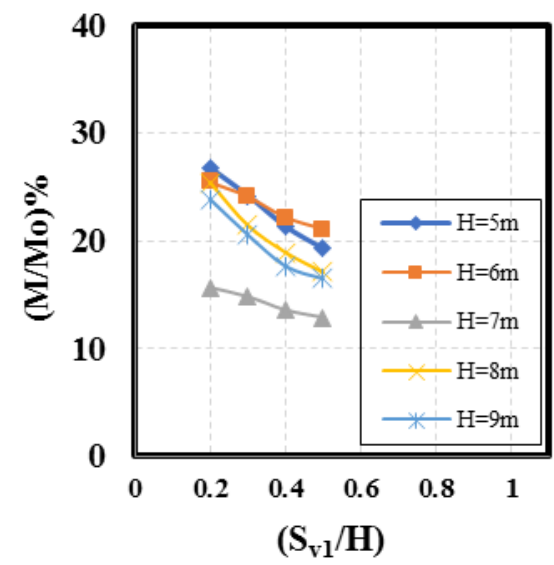

Fig. 20. Variation of the ratio of the bending moment to bending moment of cantilever wall (M/Mo), at different wall height $(\mathrm{H})$.

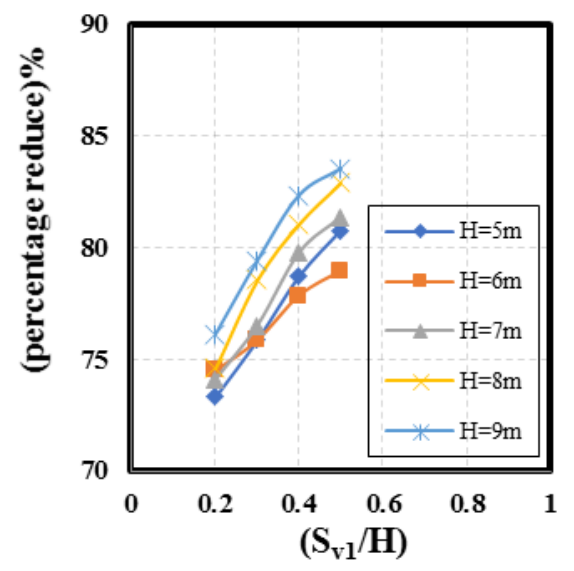

(c)

Fig. 21. Variation of the ratio of the reduction percentage of bending moment with $\mathrm{S}_{\mathrm{v} 1} / \mathrm{H}$ at different wall height $(\mathrm{H})$.

Table 15. The locations of the ratio $(\mathrm{h} / \mathrm{H}),(\mathrm{m})$ at different $\mathbf{S}_{\mathbf{v} 1 / H}$ distances for various wall height $(\mathrm{H})$.

\begin{tabular}{|c|c|c|c|c|c|}
\cline { 2 - 6 } \multicolumn{1}{c|}{} & \multicolumn{5}{c|}{$(\mathrm{h} / \mathrm{H})$} \\
\hline $\mathrm{S}_{\mathrm{vl}} / \mathrm{H}$ & $5 \mathrm{~m}$ & $6 \mathrm{~m}$ & $7 \mathrm{~m}$ & $8 \mathrm{~m}$ & $9 \mathrm{~m}$ \\
\hline 0.2 & 0.8 & 0.67 & 0.79 & 0.81 & 0.83 \\
\hline 0.3 & 0.8 & 0.83 & 0.84 & 0.81 & 0.83 \\
\hline 0.4 & 0.85 & 0.83 & 0.86 & 0.81 & 0.83 \\
\hline 0.5 & 0.85 & 0.85 & 0.86 & 0.88 & 0.84 \\
\hline
\end{tabular}

Table 16. The values of maximum bending moment, $(\mathrm{kN} . \mathrm{m} / \mathrm{m})$ and the percent of decreasing in bending moment at different $\mathbf{S}_{\mathbf{v} 1} \mathrm{y} / \mathrm{H}$ distances.

\begin{tabular}{|c|c|c|c|c|c|c|c|c|c|c|}
\hline & \multicolumn{2}{|c|}{$5 \mathrm{~m}$} & \multicolumn{2}{|c|}{$6 \mathrm{~m}$} & \multicolumn{2}{|c|}{$7 \mathrm{~m}$} & \multicolumn{2}{|c|}{$8 \mathrm{~m}$} & \multicolumn{2}{|c|}{$9 \mathrm{~m}$} \\
\hline $\mathrm{S}_{\mathrm{W} / \mathrm{H}}$ & $M_{n=}$ & 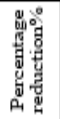 & $M_{\operatorname{mx}}$ &  & $M_{\text {mas }}$ & 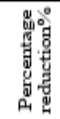 & $\mathrm{M}_{\text {SEx }}$ & 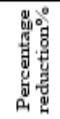 & $\mathrm{M}_{\mathrm{N}}$ & 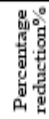 \\
\hline 0.2 & -41.1 & 73.3 & -64.2 & 74.6 & -106 & 74.11 & -155 & 74.6 & -209.1 & 76.1 \\
\hline 0.3 & -37.2 & 75.9 & -60.7 & 75.9 & .96 & 76.5 & -131 & 78.6 & -180.2 & 79.4 \\
\hline 0.4 & -32.8 & 78.7 & -55.7 & 77.9 & .83 & 79.8 & -116 & 81.1 & -154.6 & 82.35 \\
\hline 0.5 & -29.6 & 80.8 & -52.9 & 78.97 & .77 & 81.4 & -105 & 82.92 & -144.2 & 83.55 \\
\hline
\end{tabular}

Table 17. The values of the force in the anchor at various $\mathrm{S}_{\mathrm{v} 1} / \mathrm{H}$ distances at different wall height $(\mathrm{H})$.

\begin{tabular}{|c|c|c|c|c|c|c|c|c|c|c|}
\hline \multirow{2}{*}{$\left(\mathrm{S}_{\mathrm{v} 1} / \mathrm{H}\right)$} & \multicolumn{8}{|c|}{ Force in the anchors at different H values } \\
\cline { 2 - 12 } & \multicolumn{10}{|c|}{$\mathrm{kN}$} \\
\cline { 2 - 12 } & $\mathrm{H}=5 \mathrm{~m} 1$ & $\mathrm{~F} 2$ & $\mathrm{~F} 1$ & $\mathrm{~F} 2$ & $\mathrm{~F} 1$ & $\mathrm{~F} 2$ & $\mathrm{~F} 1$ & $\mathrm{~F} 2$ & $\mathrm{~F} 1$ & $\mathrm{~F} 2$ \\
\hline & 21.3 & 32.1 & 31.0 & 38.4 & 38.8 & 56.1 & 51.9 & 75.4 & 69.3 & 99.5 \\
\hline 0.2 & 26.8 & 28.5 & 32.2 & 37.9 & 41.3 & 49.0 & 57.4 & 77.3 & 69.9 & 93.2 \\
\hline 0.3 & 31.0 & 32.2 & 38.5 & 37.0 & 53.8 & 45.9 & 58.7 & 62.8 & 79.5 & 91.2 \\
\hline 0.4 & 29.9 & 24.7 & 41.9 & 32.9 & 53.5 & 44.7 & 67.8 & 62.9 & 86.2 & 77.1 \\
\hline 0.5 &
\end{tabular}

\section{CONCLUSION}

The cantilever and anchored sheet pile walls deformations and bending moment on the walls were examined with varying the dredging heights, locations of anchors and varying the number of anchors. The influence of several parameters on the wall and soil movements was investigated. Dredging height and the number of anchor levels were the 
most critical parameters to consider. Based on the variables and the ranges considered, the main findings from this research are as follows:

1. For the two-anchored sheet pile wall, the lateral wall displacements behind the wall are minimum when the anchor is installed at approximately $0.2 \mathrm{H}$ to $0.25 \mathrm{H}$ depth from the top of wall;

2. Using the one-anchored sheet pile wall can significantly decrease both maximum wall displacement and maximum bending moment; which were 59.16\%; which occurs at $0.4 \mathrm{H}$; and $85.63 \%$; which occurs at $0.5 \mathrm{H}$ respectively, comparing with the cantilever sheet pile wall at $\mathrm{H}=5 \mathrm{~m}$, however, at a large dredging depth $(\mathrm{H}=9 \mathrm{~m}), 88 \%$, and $86 \%$ reduction in maximum lateral wall displacement and maximum bending moment were observed;

3. By using the second level of anchors, the maximum bending moment on the wall can be reduced more than $83.55 \%$ and $85.54 \%$ for relatively high dredging height $(\mathrm{H}=9 \mathrm{~m}$ and $\mathrm{H}=10 \mathrm{~m})$, respectively, which occurs at a distance of $0.4 \mathrm{H}$ for both heights.

4. At $\mathrm{H}=7 \mathrm{~m}$, using the two-anchored sheet pile wall can significantly decline the maximum wall displacement and maximum bending moment; which were $10.63 \%$; which occurs at 0.2 ; and $23.89 \%$; which occurs at 0.5 respectively, comparing with the one anchor sheet pile wall.

5. At second-anchored level sheet pile wall, there is a trend of slight increase in the first anchor forces with increasing $y / h$ value, on contrary, an increase has been observed in the second anchor force for all cases studied $(\mathrm{H}=5 \mathrm{~m}, 6 \mathrm{~m}, 7 \mathrm{~m}, 8 \mathrm{~m}, 9 \mathrm{~m}$, and $10 \mathrm{~m})$ as shown in Figure 10.

6. The optimal distance for the first anchor is between $0.2 \mathrm{H}$ and $0.25 \mathrm{H}$ measured from the ground surface, however, the second anchor is $0.2 \mathrm{H}$ from the first anchor.

\section{REFERENCES}

[1]Bjerrum, L., et al., Earth pressures on flexible structures (state of the art report). 1972.

[2] Amer, H.A.R., Effect of Wall penetration depth on the behavior of sheet pile walls. 2013, University of Dayton.

[3] Smoltczyk, U., Geotechnical Engineering Handbook, Elements and Structures. Vol. 3. 2003: John Wiley \& Sons.

[4] Yandzio, E., Design guide for steel sheet pile bridge abutments. 1998: Steel Construction Institute.

[5] Bilgin, Ö. and M.B. Erten, Analysis of anchored sheet pile wall deformations, in Contemporary topics in ground modification, problem soils, and geo-support. 2009. p. 137-144.

[6] Rowe, P., Cantilever sheet piling in cohesionless soil. 1951: Verlag nicht ermittelbar.

[7] Rieke, R.D., J.C. Crowser, and W. Schroeder, Bulkhead failure investigation and redesign. Journal of geotechnical engineering, 1988. 114(10): p. 1110-1125.

[8] Abd El Raouf, M.E., NUMERICAL ANALYSIS OF ANCHORED SHEET PILE WALLS. Journal of Al-Azhar University Engineering Sector, 2020. 15(55): p. 594-603.
[9] Emarah, D.A. and S.A. Seleem, A numerical study of anchored sheet piles subjected to different types of sandy soils backfill. HBRC journal, 2018. 14(3): p. 422-430.

[10] Sowers, G. and G. Sowers, Failures of bulkhead and excavation bracing. J Civil Engineering, 1967.

[11] Smith, I. and R. Boorman, THE ANALYSIS OF FLEXIBLE BULKHEADS IN SANDS. J Proceedings of the Institution of Civil Engineers, 1974. 57(3): p. 413436.

[12] Potts, D. and A. Fourie, The effect of wall stiffness on the behaviour of a propped retaining wall. $\mathrm{J}$ Geotechnique, 1985. 35(3): p. 347-352.

[13] Day, R. and D. Potts, Modelling sheet pile retaining walls. J Computers Geotechnics, 1993. 15(3): p. 125-143.

[14] Donadio, J.V. and J.P. Grande, IgA nephropathy. J New England Journal of Medicine, 2002. 347(10): p. 738-748.

[15] Karlsrud, K. and L. Andresen, Loads on braced excavations in soft clay. J International Journal of Geomechanics, 2005. 5(2): p. 107-113.

[16] Krabbenhoft, K., et al., A new discontinuous upper bound limit analysis formulation. J International Journal for Numerical Methods in Engineering, 2005. 63(7): p. 1069-1088.

[17]. Tan, Y. and S.G. Paikowsky, Performance of sheet pile wall in peat. $\mathrm{J}$ Journal of geotechnical geoenvironmental engineering, 2008. 134(4): p. 445-458.

[18] Bilgin, Ö., Numerical studies of anchored sheet pile wall behavior constructed in cut and fill conditions. J Computers Geotechnics, 2010. 37(3): p. 399-407.

[19] Clough, G.W., Construction induced movements of in situ walls. J Design performance of earth retaining structures, 1990: p. 439-470.

[20] Endley, S.N., et al., Performance of an anchored sheet-pile wall, in Geotechnical Measurements: Lab and Field. 2000. p. 179-197.

[21] Eltaweila, S., et al., Effect of Soil Improvement Techniques on Increasing the Lateral Resistance of Single Piles in Soft Clay (Numerical Investigation). J Geotechnical Geological Engineering, 2020: p. 1-12.

[22]. Abdelhalim, R.A., et al., Experimental and numerical studies of laterally loaded piles located near oil-contaminated sand slope. Engineering Science Technology, an International Journal, 2020. 23(4): p. 744-757.

[23] Krabbenhoft, K., L. Damkilde, and S. Krabbenhoft, Ultimate limit state design of sheet pile walls by finite elements and nonlinear programming. $\mathrm{J}$ Computers structures, 2005. 83(4-5): p. 383-393.

[24] Kumar, N. and A. Dey. Finite element analysis of flexible anchored sheet pile walls: effect of mode of construction and dewatering. in Golden jubilee conference of the IGS Bangalore chapter, GeoInnovations. 2014.

[25] Morsi, Y., Berms for stablizing earth retaining structures. 2003, M. Sc. thesis, Cairo.

[26] ASTMD-1557, Standard Test Method for Laboratory Compaction Characteristics of Soil Using Modified Effort. 2012, ASTM International West Conshohocken, PA, USA. 